\title{
THE ROLE OF ENGLISH IN MODERN SOCIETY
}

\author{
Shahlo Mizrobovna Makhmudova
}

Teacher, Department of Foreign Languages,Tashkent Institute Of Chemical Technology,Tashkent, Uzbekistan

\section{ABSTRACT}

The essence of this article is about the importance of the English language and its role in the world today and the easy ways to learn English. In this article you can learn all the features of the English language, as well as find out why it is so in demand. History of the emergence and development of a foreign language, to understand the role of English in the modern world, first of all, it is necessary to know the history of its creation.

KEYWORDS:- Teaching method, different activities, grammar and linguistic structure, listening, speaking, writing, reading fairy tales, teaching method, different activities, grammar and linguistic structure, listening, speaking, writing, reading.

\section{INTRODUCTION}

It is considered the most commonly used language. More than 450 million people consider him a native. Another 600-650 million citizens use English as an additional language for communication. It is considered in demand in many countries of the world.

To understand the role of the English language in the modern world, first of all, it is necessary to know its history. It's no secret that finding out exactly how a language was formed is almost impossible. It is known that the German invaders arrived and settled in Britain in the 5th century AD. They spoke Germanic. Specialists have a small amount of information about this period. This is due to the fact that no written archives and documents of the time were found. The formation of dialects is confirmed by sources from the 7 th -9 th centuries. They all relate to the language that Alfred the Great called English in the 9 th century.
It is believed that the speech of the Scandinavians is also quite strongly influenced the development of the English language. For several centuries after the Norman Conquest, significant changes occurred in the English language. The inflectional system formed during that period is used today. According to it, grammar-specific generic endings are almost not used in English. Changes touched the vocabulary. There were borrowings from other languages, which eventually began to appear in writing. In the Late Middle Ages and the modern period, stable processes of standardization of the English language took place. Written and colloquial speech continued to change. The so-called great movement of the vowels took place. From the beginning of the seventeenth century, the influence of the English language was felt throughout the world. Over time, it began to be used by people from different countries.

Knowledge of the vocabulary and grammar of 
this language is extremely necessary in order to study abroad. Do not do without it and want to find a prestigious and highly paid job. Besides, the English language is the language of the great literature. William Shakespeare, Charles Dickens, Oscar Wilde and George Bernard Show, they all wrote their books in English. A lot of modern literature and many new films in English come out every year. If you know English, you can understand them without translation. No wonder that most educated people speak English fluently.

Interpret the following quotations:

"Language is the dress of thought". (S. Johnson)

"A thing well said will be wit in all languages". (J. Dryden)

"Words are, of course, the most powerful drug used by mankind". (R. Kipling)

"England and America are two countries separated by the same language". (G. Bernard Shaw)

"The English language is the sea which received tributaries from every region under heaven".

\section{(R. Emerson)}

"English is a language that came from nowhere to conquer the world". (G. Bernard Shaw)

Knowledge of foreign languages helps to promote cultural, educational and technical cooperation among nations. That's why one of the characteristic features of life in our country today is a great interest in the study of foreign languages - chiefly English. At present English is the most important of the world's languages. In number of speakers it ranks second. The rise of English is a remarkable success story. When Julius Caesar landed in Britain nearly two thousand years ago, English did not exist. Today English is used by at least 750 million people, and barely half of those speak it as a mother tongue. Some estimates have put that figure closer to one billion. Whatever the total, English of the 21st century is more widely spoken and written, than any other language has ever been. It has become the language of the planet, the first truly global language.

More than half of the world's technical and scientific periodicals are in English. English is the language of technology from Silicon Valley to Shanghai. English is the medium for 80 per cent of the information stored in the world's computers. Nearly half of all business deals in Europe are conducted in English. It is the language of sports and glamour: the official language of the Olympics and the Miss Universe Competition. English is the official voice of the air and sea, and of Christianity: it is the ecumenical language of the World Council of Churches. Five of the broadcasting companies in the world (CBS, NBS, ABC, BBC, CBC) transmit in English to audiences that regularly exceed one hundred million. The use of English in diplomacy, commerce and science is evidence of its importance. That's why millions of people learn it as a second language.

The importance of English in the modern world at the moment is quite large. Quite recently it was for us a foreign language, and today it is international. In all countries of the world, the study of English is of great importance. Almost everyone dreams of studying it at least at the initial level. Today, children begin to learn this language even at preschool age.

Nowadays English has become the most important language in this modern changing and

developing world. If we want to communicate, and have conversation with foreigners except, our mother tongue we need to have a common language which makes us able to join the other part of the world. English is the common 
language which is known to most of the people in the world.

The developing world demands to have good English because an effective conversation and

communication can be reached better and easily if you speak fluent English. Nowadays English is being taught to children at primary level itself. Having understood that English gives more opportunities in the future students are making a great effort to study this language attending various courses and language schools. This helps students to improve their language and get better results. But there is a question how can we improve our English? English can be improved by constant usage, by watching films, reading books with high level Grammar, playing games and trying to use new words. English can be improved by practice. As we know, practice makes the man perfect as well as using good pronunciation and grammar. Most of the jobs in today world are based on English such as IT sector, business field, call Centro jobs and teaching job, etc. So students aspiring for good jobs need to stress upon their English and usage of it because their job depends on this simple structure. English is quite easy in comparison with other languages. Basic English one can learn easily and effortlessly. Mostly people can learn English easily if they try to mater some rules and regulations. Unlike many languages, English does not have a complicated structure and except for a few areas of Grammar, it is quite simple.

It is paramount to speak English nowadays since it gives all kinds of opportunities in communication, life quality, and education. First of all, English breaks down communication barriers because it is a lingua franca. In other words, English is the most commonly used language among foreign language speakers. Throughout the world, when people with different languages come together they commonly use English to communicate. That also means that a vast majority of people around the world can speak use this language for different purposes; for example, a multicultural meeting and a chat with a foreigner unable to speak the local language are some of the situations where English is used as lingua franca. Second, English speakers are very likely to have good job opportunities. For instance, most of the Englishspeaking countries, such as England and the United States are countries with a high gross domestic product and where speaking English is the best way to get job opportunities. Therefore, the standard of living of these people can improve considerably. Finally, English- speaking countries have the best education offer in the world. In order to enter prestigious universities, such as Harvard University, Stanford University, and Oxford University, it is necessary for candidates who want to study there to speak English. Also, these countries offer lots of scholarships for foreigners that want to study in some of their universities; the only requirement besides being a good student is to have a good level of proficiency in English. In conclusion, speaking English is very important for tourists, professionals, and students who want to be successful.

English is mainly divided into two accents - US and British. US accent is very slow compared to British accent. Most people of the world follow British accent and only some people follow

American accent. In the modern world English is highly useful to have business relations as well as social network with friends and family. A better communicator can communicate effectively and this reaches people very well and chance of misunderstanding is quite less. People can be influenced with your thoughts and ideas as well as they can connect to them without much complications in understanding.

Undoubtedly English is required in today's world, as you need to communicate from the 


\section{time}

you get up till you go to bed for something or other. It is not just English is only a mode of

communication; apart from English there are many languages but English is understood by many people and is the most commonly used language. English is taught to small children at preprimary level itself. This makes understanding it easy. English is simple at the basic level but if we go deep into it, it is quite tough. The functional grammar is very hard. English must also be learnt because it is used to read various instructions on the road and many other places. It becomes a medium to study various subjects and master them. If you have good English, you can answer questions in examinations in your words as you have mastered the usage.

Any language can be master by constant usage, the more you practice the more you can

learn the language. You can watch video about various speeches about communication skills,

role play, jam section, debates and group discussion. Watch English news for updating

knowledge and movies to catch good ascent and listening skills. Watch movies with subtitle,

read newspaper, various articles in internet and good books for developing or improving

listening skills. To improve your speaking skills you must prepare power point presentation and practice explaining to your friends and take suggestion. Learn at least ten new words and

improve your vocabulary, just learning words won't make big different using them at proper

situations makes a lot of difference. Your pronunciation and ascent is observed by people so

focus more on them and try managing your voice. Speak with confidence. Apart from this play vocabulary games.

As we all have different ideas and we need to express it to other to implement them. An

effective communication means the way your word connect other and your ideas are express to other in the manner that they can follow your words and understand without any problem. It convinces the others to accept to your ideas. This is more useful in software practices as half of their work is based on communication, any miscommunication might result in loss of lots of money as well as valuable time. An effective communicator can become a successful person.Effective communication has lot of advantages in field of education, public sector, private sector and business zone also as English is required in all fields.

The reasons for learning languages vary. However, everyone agrees that all languages are meant to help in communication process. In my opinion, it's good to be born in a multi-lingual family.

It means the child will grow up knowing several languages. Otherwise, it's necessary to learn

foreign languages at school, university or any other institution. The most widespread among

foreign languages is undoubtedly English. When thinking why this old Germanic language is in such great request nowadays, I find several reasonable answers. First of all, most business fields depend on it. Secondly, it's the accepted language of modern digital era. As reported by recent statistics, almost two billion people across the world use it regularly. It's the prevalent language in travel and entertainment, in computer technologies, in medical and pharmaceutical fields, etc.

The market for learning English is simply booming. As I see it, the most significant gate that's open through the knowledge of this 
international lingua franca is the gate to career and personal growth. Knowing English is vital in many companies nowadays, while personal growth is connected with mastering the technological innovations. It's worth mentioning that almost all digital novelties are launched and exploited mainly with English language instructions. That's why employees who speak it freely are welcomed and valued.

English has quite a big role in day to day life. English is used in banks, railway stations,

bus stations, airways, educational sector, medical, private sector, etc. English is a trade language with other countries. Many students fly aboard for education and jobs. If their mode of communication is English they can manage their communication with the local people. And students are prime learners of English because if they want to build up a good career, they have to have good English speaking skills and confidence to face many people in interviews. Without English it is very tough to manage in this ultramodern world.

\section{Conclusion}

I would conclude by stating that apart from your mother tongue you need to have a common language to communicate with others and share ideas with them. English plays a role of common language between all countries. English is the official language for many countries and it plays a prominent role in all sector sof work and it is highly useful for business field and private sector.

English plays an important role in all countries. It is the official language for many

countries and it has a prominent role in all sector soft work and it is highly useful for business

field and private sector.

There are more than 300 million native speakers of English. It's the native language in such countries as Great Britain, the USA, Canada, Australia and New Zealand. It is also used as an official language in 70 and more countries of the world. This includes, Cameron, India, Pakistan, Fiji, Tanzania, Malaysia, etc. All in all, today there are almost 1000 million people in the world who know English at some extent. Even if they can't speak fluently, they understand it quite well.

English is the top language in many spheres, including business, tourism, science, education,

medicine, aviation. At the moment most Internet sites are in English and many youngsters use

English alphabet to write text messages. Millions of students worldwide attend language schools to study English, although the best way to learn a foreign language is to merge into native atmosphere. That's why many students prefer studying in English-speaking countries to improve their language skills. English dominates the media landscape as well. So many films, soaps, song lyrics are in English. And, it's surprising how many adopted English words and expressions we use in everyday life. In fact, English isn't the easiest language to learn. Just thinking of its difficult spelling and pronunciation makes me wonder why people choose to learn this language.

The answer is obvious: English unites people and helps to communicate with people from every corner of the world.

\section{References}

1. Grandall, J. 1991. Keeping up to date as ESL professional. In teaching English as a second or foreign language.

2. Parren, J. 1999. Lifelong learning, reflective practice, and teacher development.

3. Pavlenko, A. and J. Lantolf. 2000. Second 
CURRENT RESEARCH JOURNAL OF PEDAGOGICS 2(10): 209-214

October 2021 DOI: https://doi.org/10.37547/pedagogics-crjp-02-10-38

ISSN 2767-3278

(C)2021 Master Journals

Crossref dof 81 Google

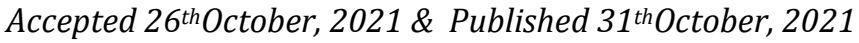

language learning as participation and the

4. (re)construction of selves. In Sociocultural theory and second language learning, ed.J. Lantolf. Oxsford: Oxford University Press.

5. Revell, J. and S. Norman. 1997. Safirre press.

6. Stevick, E.W.1996. Memory, meaning and method. Boston, MA: Heinle and Heinle.

7. Spratt, M. English for the teacher. Cambridge University. 